\title{
“ME - YOU”: SOCIAL PEDAGOGUE'S HELP FOR SOCIAL RISK CHILDREN IN TERMS OF INTERRELATIONSHIP
}

\author{
Milda Ratkevičienė \\ Klaipèda University, Lithuania
}

\begin{abstract}
Social pedagogue's help for social risk children is a relevant part of education and of our society as well in Lithuania and in the world in general. The purpose of article is to describe social pedagogue's help for social risk children through interrelationship perspective. Every relationship between social pedagogue and social risk child has different story. But the results presented in this article show all interrelationships between these two persons have the same idea - the respectful trust or trust-based respect is necessary. Only such relationships can create conditions for the provision of professional and effective help for social risk children both in short-term and long-term perspective. Interrelationship "me you" between school social pedagogue and social risk children is looked through the ideas of A. Lingis and $M$. Buber. The research is based on the phenomenological narrative perspective.
\end{abstract}

Keywords: help, social pedagogue, social risk child, phenomenology, narrative.

\section{Introduction}

The topic of social pedagogue's help for social risk children becomes increasingly relevant, because despite the development of the society, a part of, social risk children, remains an exceedingly vulnerable group. Therefore, social pedagogy in general, and a social pedagogue in particular, faces a great task of helping these children to come back to the social life.

The origins of social pedagogy are historical, yet it can be said that as a branch of pedagogy, it has emerged not that long ago. In the global context, it is perceived rather differently. Therefore, scientific discussions about social pedagogy are oriented at answering plenty of very different questions, some of them mentioned by Ezechil (2015: p. 14):

Is social pedagogy just a science? If YES, is it an independent science or interdisciplinary in nature?! Is social pedagogy a simple study discipline? Is social pedagogy a method? <...> Is social pedagogy only dealing with children and the young or also with adults?! Does it deal with disfavored / disadvantaged social categories or with all the population categories from the perspective of a specialized problematics?! 
Ratkevičienè, 2018. “Me - You”: Social Pedagogue’s Help for Social Risk Children in Terms of Interrelationship

Hämäläinen (2003) notices that social pedagogy as a tradition of thought and actions is older than the concept of social pedagogy, not to mention the term of social pedagogy itself. The idealogical origins of social pedagogy can be traced back to the ancient Greek philosophers Aristotle and Plato. According to Hämäläinen (2012), historically, social pedagogy has emerged from an idea which advanced the process of modernisation and resulted in the new societal order, characterised by the need for education to become as an intermediary in a discrepancy between individual's autonomy and the expectations of a modern society. Even though in different countries social pedagogy is perceived rather differently, according to Mylonakou-Keke (2015), analysis of social pedagogy in the context of different world locations reveals that despite space and time, social pedagogy can be noticed to possess certain common elements governing social pedagogy's philosophy, ideology, value system, theory, methodology, areas of scientific research and practice.

As noticed by Juodyte (2009: p. 21), “social pedagogy has come close to the concept of human development as socially conditioned, yet individualoriented process, which is in line with the essence of the principle of education formed by Comenius: for a person, the entire social life that takes place in the real world is a one large school.” In the contemporary society, social pedagogy occupies a very important role both solving the existing social issues and preventing them as well. At the same time, the agents of social pedagogy, namely social pedagogues, perform functions assigned to them for the aims and goals of social pedagogy to be implemented in reality. Even though there are many definitions of social pedagogy in scientific literature, they are all very similar and over-lapping: all of them emphasise the role of social pedagogues in the process of socialisation, especially their role in facilitation processes for school students, helping their families, etc. Therefore, it can be said that the main aim of social pedagogues is comprehensive social help (in the school context, it refers to help for school students).

The role of a social pedagogue is very important working with children at social risk. According to Böhnisch and Schröer (2011), children and teenagers are the most vulnerable age groups. Therefore, the line between a child and a social risk child is sometimes a very fine one indeed.

Etzion and Romi (2015) claim that the concept of a social risk child defines a part of children population which is in a physical, psychological or spiritual peril. When speaking about problems related to children at risk Lovitt (2010: p. 317) claims:

Thousands of children are living in stressful and dysfunctional situations. Scores of them reside in conditions replete with drugs or alcohol. Many children live in circumstances of abject poverty. Indeed, hundreds of them are homeless and live in automobiles, parks, or on streets. Other children are in situations in which 
violence of one type or another is common. Some of these children are living with two parents, but many are with a single parent. Great numbers of children are placed with relatives (often grandparents). Yet others reside in foster homes, group homes $<\ldots>$.

According to the Social Map of Lithuania (2016b), in 2014, the rate of social risk families has been 4.73 per one thousand inhabitants of Lithuania. Moreover, according to the Social Map of Lithuania (2016a), the rate of children raised in social risk families is slightly more than 56 per one thousand children. Social pedagogue's help serves as one of the key actions applying preventive and problem-solving measures working with children at social risk. Social pedagogue's help takes place in various forms not only in Lithuania, but the entire world as well.

Leliūgienè (2003) has noted that social pedagogue is a person who usually has an opportunity to diagnose the problems of children at social risk, find solutions for the subsequent rehabilitation of such minors and decide on methods and instruments to work with them. However, studies focusing on social pedagogues in the context of the provision of socio-pedagogical help are relatively scarce. A more extensive study on this topic has been conducted by Baraldsnes and Vaškienè (2013). The said study analyses challenges faced by social pedagogues when providing socio-pedagogical help. Numerous foreign research (Kozan et al., 2014; Schuitema et al., 2016; Liu et al., 2016; Wood et al., 2017; Tian et al., 2015) focuses on the provision of social support. Klaniene and Šmitiene (2013) has noticed that there exists a lack of scientifically-based research and recommendations regarding the provision of socio-pedagogical help to social risk children. According to Klaniene and Šmitiene (2013), these studies and recommendations could form foundation offering targeted/specific recommendations related to the effectiveness of the individual functions of a social pedagogue. Therefore, research focusing on the help of social pedagogues to children at social risk could lead to improving the situation and increasing the efficiency.

The study introduced in this article aims at describing social pedagogue's help for social risk children in terms of interrelationship. Research subject is social pedagogue's help for social risk children.

\section{Methodology}

The study introduced in this article has been based on a qualitative approach, taking into consideration that its subject is oriented at human interrelationship. According to Dietrich (2011), when analysing human relationship and experiences, the aim is to reveal why and how do these phenomena take place and explain them as well, and in such case, qualitative 
Ratkevičiene, 2018. “Me - You”: Social Pedagogue’s Help for Social Risk Children in Terms of Interrelationship

study is appropriate and acceptable. This study is conducted combining the narrative approach and phenomenology. According to Clandinin (2006), a narrative-based approach enables understanding how a social and a personal experience gradually intertwines as people's lives advances, because their individual experience is determined by greater social, cultural and institutional narratives that have been and still are inhabited by people. At the same, phenomenology, according to Van Manen (2014), aims at looking straight at the core of the phenomenon, describing and analysing the instantaneous experiences of people who have been exposed to such phenomena. According to Van Manen (2014), when conducting research, those who are engaged in the phenomenology of practice pose a question of what it is, rather than why? However, both the narrative and phenomenology raise some very important and relevant questions and even though the focus is not on receiving specific answers to them, they encourage thinking and analysing problems. The final text in both narrative and phenomenology does not ever mean that the final answer will be provided; it does not aim at creating practical tools and models regulating "how one should live" and does not develop theories that would help explaining and/ or controlling the world (Clandinin et al., 2016; Van Manen, 1990). Experts of the narrative employ collaboration and ethics in order to enable the audience to rethink, retell, take a better look into one's experience, reconsider how they operate and are related to others (Clandinin et al., 2016), why those who specialise in the phenomenology of practice analyse real-life problems as well, yet they aim at producing a comprehensive description of a phenomenon in question (Van Manen, 1990).

It is noteworthy that research data is collected by the application of the narrative. The total of nine social pedagogues have participated in the study. Seven of them have been interviewed using the narrative approach to the the indepth interview. The other two participants have provided their answers in writing. Additional material necessary for the study has been collected applying the following two methods: a structured interview and additions made in writing to participant stories, their notes and documents. The subsequent research has employed stories only by five respondents restructured into seven narratives. The article introduces fragments of the narrative from two research participants. In order to comply with the principle of confidentiality, the names of participants and children mentioned in the narratives have been changed.

Research data provided in this article is analysed applying the phenomenological approach. Even though phenomenological research usually employs short and vivid stories (anecdotes), in case of this study, it is only employed only as an analytical method that enables a more extensive analysis of narratives collected conducting this research. Therefore, stories illustrating the analysis are excerpts from the narratives on socio-pedagogical help for social 
risk children that comply with requirements for narrative-based approached research.

According to Batuchina (2015) (quoting Van Manen, 1990), there are several existentials characteristic to all phenomena: lived relation, lived body, lived space and lived time. This article introduces the aspect of relationship between social pedagogues and social risk children in the context of sociopedagogical help for social risk children.

\section{Results}

Our relationships with each other are affected by plenty of factors and based on various feelings and aspects. However, stories told by social pedagogues reveal that the most important aspects of relationship between a social pedagogue and a social risk child (and thus the recipient of help) are respect and trust. In my opinion, respect and trust are the most important elements of any relationship. And both of them are rather hard to earn. To quote Leonardo da Vinci, respect cannot be gained through force but rather through goodness and ability to share your last morsel with the poor. It means that you cannot force a person to respect you. Respect cannot be purchased or imposed on someone. The same applies for trust. Lingis (2010: p. 87) claims that "the deepest and most profound relations are made when you trust someone and when you trust the unknown with your life.” Social pedagogues usually work with the most vulnerable children who have faced various difficulties in life and been disappointed in a lot of things and relationship with people. It is not easy to earn trust and respect of such children. Therefore, it is important to understand how social pedagogues earn trust and respect of social risk children and how such relationship develop in general.

An illustration of relationship between Dainora and Domas based on trust and respect is provided below:

Since the very beginning of our acquaintance, he communicated with me rather willingly. At the beginning not so much maybe, but later he's understood that I am not a punishment, because social pedagogues are usually described as the punishment: "if you are bad, you will go to a social pedagogue". It is very difficult to provide help, when you are perceived as a punishment. And you must work with a child somehow, even though he or she imagines that you are just someone who chastises them. Domas has never been afraid of communicating with me. On the contrary, Domas himself has been prone to initiate the contact. A lot of depended on what kind of day it was at home. He trusted me. He never lied to me. Either he told me nothing or told things the way they were. If something happened, he would always come to me, because teachers were rather set against him because of his insolent behaviour. There used to be a lot of conflicts during the lessons because he has always been very dissatisfied with his 
Ratkevičiene, 2018. “Me - You”: Social Pedagogue’s Help for Social Risk Children in Terms of Interrelationship

life. Maybe it has to do with his mother's death? And he used to get into conflicts with teachers. And teachers, in their turn, used to blame Domas at once if something happened. But he used to communicate with me. So always, if there is some sort of problem, he used to come and tell me about it. If something was his fault, he used to avoid me, but if someone blamed him unjustly, he used to come even before the teacher did, and told me the entire story. (Dainora)

First of all, Dainora's story reveals that a social pedagogue usually faces obstacles when trying to earn child's trust and respect, because as Dainora stated, teachers usually describe a social pedagogue as a punishment and an executioner of sorts who imposes a sentence on a transgressed child. Naturally, children are frightened this way, and the process of earning respect and trust becomes even more complicated; as stated by Dainora, "it is very difficult to provide help, when you are perceived as a punishment." According to Lingis (2010, p. 67), "fear is fear of something unknown; it is not a simple reaction to a situation to something that turns out to be clearly dangerous." A similar idea has been expressed by Daniel Defoe: "fear of danger is ten thousand times more terrifying than danger itself". This means that fear goes side by side with the unknown. Therefore, social pedagogue who aims at earning trust and respect, first, needs to help a child to overcome the feelings of fear and uncertainty frequently experienced by social risk children and directed to the social pedagogue himself/ herself.

Once children overcome the barrier between themselves and social pedagogues, the latter can expect to establish a connection with the former. Dainora recalls that even though Domas would get into conflicts with teachers and found it difficult to communicate with them, but there have not been any problems communicating with a social pedagogue: he would initiate the contact and be the first to tell her about his problems. This shows that Domas trusts Dainora despite the fact whether the situation has been his fault or not. According to Lingis (2010), we establish trust without possessing knowledge, i.e. we do not have to know a person in order to trust him/her: sometimes it does not depend on us.

The fact that Domas tends to talk back to teachers but communicates and opens to the social pedagogue rather willingly shows that he respects Dainora and trusts her as a person who cares, listens to him and does not jump to unfavourable conclusions without learning about the situation first (a situation he has experienced when communicating with his teachers). Such a bond between Dainora and Domas has facilitated the options to provide sociopedagogical help to a child.

Giedre recalls a specific event which reveals how a trust between her as a social pedagogue and a girl has developed. 
When I arrived at work, I found Dija on the ground floor pressed against a radiator. She was very sad and upset. I approached the girl and asked whether she is up for a talk. Dija told me that her mother was drinking throughout the entire weekend. She couldn't sleep for the entire weekend either, because the house was full of noisy drunkards. I asked her whether she had had something to eat that day and Dija told me that she hadn't had any breakfast that morning, because there is not a morsel of bread or tea at home, not to mention butter... This broke my heart. The girl spent the first lesson in my office. I made her some tea and a sandwich. The girl opened and talked to me; it was evident that after our conversation she felt relieved. Later she even managed to smile. (Giedré)

Giedre states that when she has arrived at school, she has found Dija crying. When she invited the girl to talk, she could either receive consent or refusal to do it. Therefore, her consent has been the first sign that the girl trusts her. Lingis (2010: p. 87) states: "I think that the deepest and most profound relations are made when you trust someone and when you trust this unknown entity with your life.” Girl's trust in her social pedagogue not only makes her feel better ("Later she even managed to smile") but by talking about her problems she also opens up about her life, which she probably has not done before.

Child's trust in a social pedagogue in terms of socio-pedagogical help to a social risk child is very important; it allows the child to talk and reveal his/ her problems. According to Lingis (2010), trust helps to form a deeper bond between people. In this situation, it can be stated that trust in a social pedagogue allows a child to share his/ her problems and thus expect to receive help, because otherwise, mistrusting the social pedagogue, Dija could have told nothing about her experience and suppress it. Therefore, when speaking about socio-pedagogical help to social risk children, trust enables a social pedagogue to discover child's problems sooner, analyse them to a deeper extent and start providing help immediately.

Both stories have revealed the importance between a social pedagogue and a child receiving his/ her help. Buber (1962/1998) defines three kinds of dialogue: genuine, technical and dialogue-based monologue. According to Buber (1962/1998: p. 71), a genuine dialogue is a dialogue which can be both spoken or silent, but "where each of the participants really has in mind the other or others in their present and particular being and turns to them with the intention of establishing a living mutual relation between himself and them.” In the context of an interaction between a social pedagogue and a social risk child, I place emphasis on this, genuine, dialogue, because it essentially defines the dialogue between a social pedagogue and a social risk child. Therefore, such a dialogue must be inevitably based on a living mutual relation and participants in a dialogue, and as Buber (1962/1998) claims, they must inevitably turn towards 
Ratkevičiene, 2018. “Me - You”: Social Pedagogue’s Help for Social Risk Children in Terms of Interrelationship

one another; only then their interaction will be a successful one. Such dialogues between a social pedagogue and a social risk child, according to Buber (1962/1998), can take place without any external signs. The stories of both Dainora and Giedre have revealed that sometimes there do not have to be any words passed between a social pedagogue and a social risk child for them to develop a bond: a child simply need a look or an action to see that a social pedagogue is a human being who can be trusted.

However, trust and respect in the "Me - You" relation should go both ways: from the child to the social pedagogue and vice versa. The best illustration for it is Dainora's story provided below:

There's no need to lose positivity, I guess. But what if children see different things? We cannot explain them that things may go either this or that way, you must behave this way, do these things and have these goals. Because they go back to their families and see different things: they see drunk parents, violence and things that happen in their families but not what we tell them about. And they cannot change their ways. These are the ways that help them to survive. And you cannot change anything. You can incept these thoughts, but you cannot make choices for them. You cannot live for them. Domas is good on the inside, but his living conditions, his family and circumstances have arranged themselves in a way which forces him to renounce the hope for everything to ever be better. Even though he tries really heard. Yet I think that there is a positive change: I don't think that he will sink as low as he could have. I see that he does sports. I think that it's not bad. But they are used to survive rather than to live. Others are defended by parents. It does not matter what they do, parents always have their backs. And he hasn't had this support. We were here, but he missed his parents. (Dainora)

This part of Dainora's story while revealing that sometimes the outcomes of help for social risk children are not the ones a social pedagogue expects, yet it also reveals an unconditional pursuit for positivity, her respect for a child and believe in him/ her. Dainora evaluates the situation of Domas critically: she understands that there might have been more of the negative rather than positive factors in his life, yet she finds some positive stages and solutions. Dainora's story radiates trust and faith in this child, respect for him as a human being, his life and his choices, even though they are not always the ones as expected by a social pedagogue who provides help. When discussing trust, Lingis (2010: pp. 84-85, 87) introduces an insight based on his life experience:

Therefore, if you start trusting someone, this trust must gradually increase. If you feel that you are trusted, you trust yourself more. <...> Therefore, a person leading you through the jungle must trust not what he knows, but oneself and one's ability to find the way. And when you trust him, his self-confidence increases, and he becomes braver. 
$<\ldots>$ I also think that trust characteristic to this relation is the basis for all of our relationship. Every time you establish a friendly relation you risk something. Because of this reason, friendship is not only safe and comforting but also exciting.

It means that trusting another person provides an opportunity to trust yourself more, yet trust involves a certain risk. Lingis (2010: p. 81) claims that "when we trust someone, there is always some risk involved. To trust is to take a risk. Speaking, building, creating, living is to take risks", i.e. trust so as everything else in our life is a risk of sorts. However, despite the risk, we do not have to cease trusting others. Trust enables us to respect the choices and actions of others.

Stories told by both Dainora and Giedre reveals the importance of the role of trust in the process of provision of socio-pedagogical help to social risk children; yet what it is more important, is the trust for a person next to us. Trust and respect in this process are interrelated. This is how it becomes possible to see a social pedagogue like a sort of support for a child, who helps to solve their problems that a child could not have solved alone. There is a passage in Women Who Run with the Wolves: Myths and Stories of the Wild Woman Archetype by Estés (2005: pp. 157-158):

Feeling his death approaching, one old man gathered all of his relatives to his deathbed. To each of his many children, wives and relatives he gave a short, thick rod and asked to break it in half. They gathered they forces and managed to break their rods.

"This is what happens when you are alone without anyone in the world. You are easy to break."

Then the old man gave his relatives another rod each and continued talking:

"This is how I want you to live when I'm gone. Place your rods together in twos and threes. And try to break them now."

No one managed to break them all at once. The old man smiled.

"We are strong only when there are two of us. When there is someone next to us, no one can break us."

This excerpt shows that in the life of individuals, people around and interaction with them is important. The effect is synergistic: one plus one is not just two. Sometimes it is more than three. I have chosen this story for a purpose. It resonates with a discussion of socio-pedagogical help to social risk children. Stories describing the experience of social pedagogues show the importance of their role and the dialogue between them and children receiving help. The stories told by social pedagogues have revealed that children in their stories usually are lonely, neglected and highly vulnerable. In these particular relationships based on respect and trust, a social pedagogue becomes as a sort of rod for a child described by Estés (2005), having this support, a child will not break that as easy as left alone. 
Ratkevičiene, 2018. “Me - You”: Social Pedagogue’s Help for Social Risk Children in Terms of Interrelationship

It is not important how we are going to describe a relation between a social pedagogue and a social risk child: respectful trust or trust-based respect; the most important thing is such foundation of relationship between them enables a social pedagogue to provide help for social risk children: maybe it is not always as efficient as intended by the social pedagogue, but it is important that there are an opportunity to provide it in the first place.

\section{Conclusions}

Socio-pedagogical help provided to social risk children is a complex and difficult process focusing on the solutions and prevention of social problems. Even though there exist plenty of studies focusing on socio-pedagogical help, the need for comprehensive qualitative studies focusing on the help itself still exists. Taking it into consideration and combining phenomenology and the narrative approach, this study focusing on socio-pedagogical help for social risk children has been conducted.

The article introduces results of a study that deal with social pedagogue's help for social risk children in terms of interrelationship. From the perspective of the narrative-phenomenological approach, study results have revealed that relationship between a social pedagogue and a social risk child are based on mutual trust and respect. Relationship based on trust and respect enables a child to open to the social pedagogue and thus results in a timely and more efficient provision of help. It is not important how a relation between a social pedagogue and a social risk child is described: respectful trust or trust-based respect; the most important thing is such foundation of relationship between them enables a social pedagogue to provide help for social risk children: maybe it is not always as efficient as intended by the social pedagogue, but it is important that there is an opportunity to provide it in the first place.

\section{References}

Baraldsnes, D., \& Vaškienè, D (2013). Socialinio pedagogo iššūkiai organizuojant ir teikiant socialinę-pedagoginę pagalbą mokiniams mokykloje. Tiltai, 1, 199-210.

Batuchina, A. (2015). Vaiku migravimo fenomenologinis tyrimas. Daktaro disertacija. Klaipėdos universitetas.

Böhnisch, L., \& Schröer, W. (2011). Social Pedagogy of the Life Stages. In Kornbeck, J., Jensen, N. R. (Eds.) Social Pedagogy for the Entire Lifespan, Volume 1. Bremen: Europäischer Hochschulverlag, 15-29.

Buber, M. (1962/1998). Dialogo principas II. Dialogas. Klausimas pavieniui. Tarpžmogiškumo pradai (Trans. T. Sodeika). Vilnius: Katalikų pasaulis.

Clandinin, D. J. (2006). Narrative Inquiry: A Methodology for Studying Lived Experience. Research Studies in Music Education, 27, 44-54. 
Clandinin, D. J. et al. (2016). Engaging in Narrative Inquiries with Children and Youth. New York: Routledge.

Dietrich, C. (2011). A Phenomenological Study of Social Science Instructors' Assessment Practices for Online Learning. Doctoral Dissertation. Walden University.

Estés, C. P. (2005). Bègančios su vilkais. Laukinès Moters archetipas mituose ir pasakose. Vilnius: Alma Littera.

Etzion, D., \& Romi, S. (2015). Typology of youth at risk. Children and Youth Services Review, 59, 184-195.

Ezechil, L. (2015). Social pedagogy - new perspectives. Procedia - Social and Behavioral Sciences, 180, 13-18.

Hämäläinen, J. (2003). The Concept of Social Pedagogy in the Field of Social Work. Journal of Social Work, 3(1), 69-80.

Hämäläinen, J. (2012). Social Pedagogical Eyes in the Midst of Diverse Understandings, Conceptualisations and Activities. International Journal of Social Pedagogy, 1 (1), 316.

Juodaitytè, A. (2009). Sociologinès paradigmos raiška edukologijoje: naujos žinios ir socialinès pedagogikos statusas. Mokytoju ugdymas, 13 (2), 10-25.

Klanienė, I., \& Šmitienė, G. (2013). Risk group children: characteristics of their socialpedagogical counselling. Changing education in a changing society, 2, 50 - 57.

Kozan, S. et al. (2014). The Role of Social Support and Work-Related Factors on the School Engagement of Italian High School Students. Journal of Career Assessment, 22 (2), 345-354.

Leliūgienè, I. (2003). Socialinè pedagogika. Kaunas: Technologija.

Lietuvos socialinis žemèlapis (2016a). Socialinès rizikos šeimose augančių vaikų skaičius 1000-iui vaikų. Retrieved from: http://www.socialiniszemelapis.lt/index.php?rod=9.

Lietuvos socialinis žemèlapis (2016b). Socialinès rizikos šeimų skaičius 1000-iui gyventojų. Retrieved from: http://www.socialiniszemelapis.lt/index.php?year=2014\&rod=8.

Lingis, A. (2010). Bendra kalba, paskiri balsai (Trans. D. Bacevičiūtè). Vilnius: UAB „Baltų lankų"leidykla.

Liu, W. et al. (2016). Age and Gender Differences in the Relation Between School-Related Social Support and Subjective Well-Being in School Among Students. Age and Gender Differences, 125, 1065-1083.

Lovitt, T. C. (2010). What Teachers Can Do for Children Living in Difficult Circumstances. Intervention in School and Clinic, 45 (5), 317-320.

Mylonakou-Keke, I. (2015). 1844-2014: 170 Years of Social Pedagogy - Can Greece’s Economic Crisis Highlight the Potential of Social Pedagogy? International Journal of Social Pedagogy - Special Issue 'Social Pedagogy in Times of Crisis in Greece', 4 (1), 2-23.

Schuitema, J. et al. (2016). Longitudinal relations between perceived autonomy and social support from teachers and students' self-regulated learning and achievement. Learning and Individual Differences, 49, 32-45.

Tian, L. et al. (2015). School-related social support and subjective wellbeing in school among adolescents: The role of self-system factors. Journal of Adolescence, 45, 138148.

Van Manen, M. (1990). Researching Lived Experience. Human Science for an Action Sensitive Pedagogy. New York: State University of New Your Press.

Van Manen, M. (2014). Phenomenology of Practice. California: Left Coast Press.

Wood, L. et al. (2017). School personnel social support and nonsupport for bystanders of bullying: Exploring student perspectives. Journal of School Psychology, 61, 1-17. 